\title{
Promoting Women Literacy through Community Education in Enugu State, Nigeria
}

\author{
Loretta Chika Ukwuaba \\ Enugu State University of Science and Technology Enugu, Nigeria
}

\begin{abstract}
The study examined the extent community education promotes literacy among women in Enugu State. Three research questions guided the study. The population for the study was 68 community development officers from the 17 local Government Areas and 51 development centres in Enugu State. The entire population was used for the study due to the manageable number. A structured 21-itemed questionnaire with response options of very great extent (VGE), great extent (GE), low extent (LE) and very low extent (VLE) developed by the researcher was the instrument used for the study. The instrument was validated by experts in the fields of education and a reliability coefficient of 0.76 was obtained using cronbach alpha method of determining internal consistency of the instrument. The Data collected was analysed with mean scores and the upper and lower boundary limits were used to decide the rate of acceptability. Findings from this study revealed that there is a link between community education and improvement in literacy among women. Community education to a great extent has contributed to eradicated illiteracy among women in Enugu State. Also community education has to a great extent contributed to the development of women literacy programmes in the state. However, the study revealed that communities have to a low extent collaborated with government, non-governmental organization (NGOs) and religious organizations for women literacy development in the state. The researcher recommended among other things, that, communities should be sensitized on the need for collaboration with government, NGO's and religious organizations for effective women literacy development.
\end{abstract}

\section{Introduction}

Illiteracy in Nigeria is both a cause and a consequence of poverty, deprivation, ignorance and underdevelopment. It is commonly accepted that the gains of development cannot reach the general population until basic education and literacy are provided to all, particularly women. Literacy is not merely about basic skills of reading and writing, it is about providing individuals with the capabilities of understanding their lives and social environment as well as equipping them with problem-solving skills. Literacy therefore is a foundation of human resource development and is critical to alleviating poverty and the enhancement of the general quality of people's lives [1].

In today's globalized world, literacy has become essential to collective advancement. Not only are those who are not literate cut-off from their opportunities for advancement, but the society as a whole is also deprived of the potential contribution that these individuals can make to the good of all. The United Nations report cited in Adeoye, revealed that more than 861 million adults the world over are illiterate, majority of which are women [2]. In addition to these facts some 113 million children are not in school and risk living out their adult lives as illiterates. The period between 2003-2013 has been proclaimed as the United Nations Literacy Decade and the United Nations Educational, Scientific and cultural organization (Unesco) in 2003 developed a simple but powerful slogan for the decade "Literacy as freedom". This slogan illustrates the way in which illiteracy also prevents an individual from participating in the "give and take" of democracy and other social interaction that make diverse societies work in the modern world [3].

The Global experience of communities in promoting literacy can offer much as the world considers how best to promote women literacy during the United Nations Literacy Decade [4]. Developed countries like Russia, United States of America, Bolivia, India among other countries have addressed women literacy in a variety of ways. In India, women's literacy is recognized as a fundamental human right. Knowledge to the Indian's is wings to man's life and a ladder for his ascent. The acquisition of knowledge is incumbent to everyone [5].

In Nigeria today, most communities have become deeply involved in women's literacy development. Literacy development for women is particularly 
valuable as a strategic investment in human resource as the social returns are high. The literacy for women has a tremedious impact not only on their own development but also on that of their family and community. It acts as a catalyst in virtually every dimension of development and poverty alleviation with outcome, such as reduced fertility, reduced infant mortality improved child survival, better family health, increased educational attainment, high productivity and general improvement in the nations economics status [6].

The development of women's literacy could be achieved through community education. Community education simply means education in the community for the growth and development of that community. Community education is an organizational programme to promote learning and social development works with individuals and groups in their communities using a range of formal, non-formal and informal methods [2]. The common features in the definition of community education is that programmes such as, health education, income generating skill programmes, family planning programmes, nutrition education programmes etc and other activities are developed in dialogue with community and participants to promote learning and social development.

Community education is developed in response to low literacy level among adult particularly women, high drop-out rate among youths and corresponding lack of resident participation in community development effort in the areas. Community education to Karl, is an instrument to foster literacy development for positive personality, self-awareness and self confidence among women [7]. It creates awareness about harmful social practices such as early marriage, widowhood practices etc and gives women who dropped out of school opportunity to continue their educational career. Community education offers women opportunity to gain literacy skills which is an important step towards promoting positive change. It also provides facilities that will facilitate literacy education among women [8].

The basic goal of community education as summarized by [9] include the following: upgrading human capabilities, mainly through education and training, to individuals to develop to their maximum potentials; incorporation of greater awareness in functional literacy and post literacy programmes; stressed development of the technical and managerial capacity of NGOs running such programmes; strengthening functional literacy with the support of government and other NGOs and eradication of illiteracy through programmers and initiatives tailored to suit the lifestyle of the community.

Illiteracy is observed as a serious obstacle to development. Community education strive to reverse high rate of illiteracy in many communities by engaging and strengthening collaboration between government and non-governmental organizations that focus on rural areas through training and capacity building [10]. The collaboration of religions bodies and other functional local authorities have proven to be an effective avenue to set up result-oriented literacy classes for women. Women literacy programmes should be packaged taking into cognizance the women's expectations and shaping their texts to meet such expectations.

Through community education there have been collaborations between international organizations like UNESCO and African Cultural centre for UNESCO beginning at the project design [11]. Such collaborations help to strengthen the ability for planning, executing monitoring and evaluating programmes among grassroot organizations striving to curb high rate of illiteracy especially among girls and women in Africa.

Community education, transcends barriers by linking women literacy education and community development through community based approach to women literacy [12]. Community education serve as a catalyst for transformation in the lives of women it serve by reducing the rate of illiteracy to achieve human resource development. The roles of women education in community building are in the areas of developing the ability to express personal experiences and observed phenomena; constructing one's own knowledge; setting and following through one's goals; building a positive community environment; developing a vision of the community education. This indicates that women literacy development can be structured to successfully build the capacity of participants to engage in community development processes as agents of change for members of their communities [13].

Community education thus strives to reverse high rates of women illiteracy to achieve human resource development. Eradication of illiteracy among women through community education involves integrated community development, which will subsequently encourage women to embrace education, employing the house-to-house campaign and home visitation programme to disseminate information and encourage literacy among the women folk [14].

Community education offers women the opportunity to gain literacy skills which is an important step towards promoting positive change. Many communities in Enugu State has initiated literacy programmes for women though community education. The study therefore sorts to determine the extent community education promotes women literacy in Enugu State, Nigeria. 


\section{Statement of problem}

In Nigeria about $68 \%$ of women are not literate and so do not possess the capacities for understanding their lives and social environment as well as equipping themselves with problem solving skills. Many organizations have engaged in a series of activities and projects to address the problems of low level of literacy among women. These programme and activities were meant to enhance their quality of life, yet the level of responses for literacy programmes continue to be discouraging, a scenario that remains a source of worry to government, non-governmental organizations, community based organizations and stakeholders in the eradication of illiteracy among women

This poor response to women literacy, prompted many communities in Enugu State to embark on programmes and activities aimed at eradicating illiteracy among women in their areas. Through community education, adult basic education and skill centres were established in communities to expose illiterate women to practical skills in the art of reading and writing to acquire vocational skills for income generation and other skill. The problem of this study therefore was to determine the extent community education has promoted women literacy in Enugu State, Nigeria.

\section{Purpose of the study}

The general purpose of this study was to determine the extent community education promotes women's literacy in Enugu State.

Specifically, the study determined the extent to which community education;

- Has contributed to the eradication of illiteracy among women in Enugu State.

- Enhanced development of literacy programmes for women in Enugu State,

- Collaborated with government and nongovernment organizations for effective development of literacy programmes for women in Enugu State.

\section{Research Questions}

- To what extent has community education contributed to the eradication of illiteracy among women in Enugu State?

- To what extent has community education contributed to the development of literacy programmes for women in Enugu state.
- To what extent have communities through community education strengthened collaboration with government \& nongovernmental organization for effective women's literacy development in Enugu State.

\section{Research Methods}

A survey research design was employed in carrying out the study. The population for the study was sixtyeight (68) community development officers in the seventeen (17) Local Government Areas and fifty one (51) Local Government Development Centres in Enugu State [15] No sampling was done, due to the small population. The entire population was used for the study.

The instrument used for data collection was a 21itemed four point scale structured questionnaire with response options of very great extent (VGE), great extent (GE), low extent (LE), and very low extent (VLE). The instrument was validated by experts in the fields of education from Enugu State University of Science and technology Enugu. A reliability coefficient of 0.76 was obtained for the instrument using cronbach alpha's formular of determining internal consistency of an instrument. Sixty-eight (68) copies of the questionnaire were distributed to the respondents and all the copies were returned. This gave a percentage return rate of $100 \%$.

The data collected was analysed with mean. The principles of lower and upper boundary limits of the mean was used to decide thus; mean of $3.50-4.00$ was accepted to a very great extent; $2.50-3.49$ accepted to a great extent; 1.50-2.49 accepted to a low extent and $1.00-1.49$ accepted to a very low extent.

\section{Results}

The results of the three research questions were presented in tables as follows:

Table 1: Mean scores of respondents on the extent to which community education has contributed to the eradication of illiteracy among rural women in Enugu State.

$\mathrm{n}=68$

\begin{tabular}{|c|c|c|c|}
\hline $\mathbf{S} / \mathbf{N}$ & Items & $\overline{\mathbf{X}}$ & $\begin{array}{l}\text { DECI } \\
\text { SION }\end{array}$ \\
\hline & $\begin{array}{l}\text { Through community } \\
\text { education communities }\end{array}$ & & \\
\hline 1 & $\begin{array}{l}\text { Encouraged women to be } \\
\text { proactive in participating in } \\
\text { education; }\end{array}$ & 3.4 & GE \\
\hline 2 & Promotes effective campaign & & \\
\hline
\end{tabular}




\begin{tabular}{|l|l|l|l|}
\hline & $\begin{array}{l}\text { on the need to embrace } \\
\text { literacy among women }\end{array}$ & 3.90 & VGE \\
\hline 3 & $\begin{array}{l}\text { Fund women literacy } \\
\text { programmes }\end{array}$ & 3.0 & GE \\
\hline 4 & $\begin{array}{l}\text { Recruit adult literacy } \\
\text { facilitators }\end{array}$ & GE \\
\hline 5 & $\begin{array}{l}\text { Make specific efforts to } \\
\text { target vulnerable and } \\
\text { disadvantaged women }\end{array}$ & 2.38 & LE \\
\hline 6 & $\begin{array}{l}\text { Provides facilities eg books, } \\
\text { libraries etc to promote } \\
\text { women literacy }\end{array}$ & 2.75 & GE \\
\hline 7 & $\begin{array}{l}\text { Encourage home visitation } \\
\text { programmes for women } \\
\text { literacy }\end{array}$ & 2.11 & LE \\
\hline & \begin{tabular}{l} 
Grand mean \\
\hline
\end{tabular} \\
\hline
\end{tabular}

In Table 1, item 1, 2, 3, 4, 6, have mean of 3.4, 3.9, $3.0,3.13$ and 2.75 respectively. This indicates that the respondents agreed that these community efforts has enhanced the eradication of illiteracy among women in the state Items 5 and 7 on the contrary have means of 2.38 and 2.11 which show a low commitment of the communities on these items towards eradication of illiteracy among women in Enugu State. However, a grand mean of 2.96 was obtained from all the 7 items, this implies that the respondents agreed that community education has to a great extent enhanced the eradication of illiteracy among women in Enugu State.

The computed mean on this table showed that items $10,11,13$ and 14 has a mean score of $2.85,2.79,3.0$ and 2.51. This indicates that these literacy programmes, were developed in the communities through community education to a great extent, while items $9,10,12$ and have a mean scores of 2.30, 2.29 and 2.19 which shows that these women literacy programmes were developed to a low extent through community education. A grandmean of 2.56 was obtained indicating that generally community education has contributed to development of women literacy programmes in Enugu State.

Table 2: Mean scores of responded on the extent to which community education has contributed to the development of literacy programmes for women in Enugu State.

$$
\mathrm{n}=68
$$

\begin{tabular}{|l|l|l|l|}
\hline $\mathbf{S} / \mathbf{N}$ & Items & $\overline{\mathbf{X}}$ & $\begin{array}{l}\text { DECI } \\
\text { SION }\end{array}$ \\
\hline & $\begin{array}{l}\text { Through Communities } \\
\text { education, Communities }\end{array}$ & & \\
\hline
\end{tabular}

\begin{tabular}{|l|l|l|l|}
\hline & provides; & & \\
\hline 8 & $\begin{array}{l}\text { Family planning literacy } \\
\text { programme for women }\end{array}$ & 2.19 & $\mathrm{GE}$ \\
\hline 9 & $\begin{array}{l}\text { Political literacy } \\
\text { programmes for women }\end{array}$ & 2.30 & $\mathrm{LE}$ \\
\hline 10 & $\begin{array}{l}\text { Healthful living } \\
\text { programme for women }\end{array}$ & 2.85 & $\mathrm{GE}$ \\
\hline 11 & $\begin{array}{l}\text { Income generating skills } \\
\text { activities for women }\end{array}$ & 2.79 & $\mathrm{GE}$ \\
\hline 12 & $\begin{array}{l}\text { Decision-making skills } \\
\text { programmes for women }\end{array}$ & 2.29 & $\mathrm{LE}$ \\
\hline 13 & $\begin{array}{l}\text { Financial literacy skills } \\
\text { programmes for women }\end{array}$ & 3.0 & $\mathrm{GE}$ \\
\hline 14 & $\begin{array}{l}\text { Workshop and Seminars } \\
\text { on vital issues }\end{array}$ & 2.51 & $\mathrm{GE}$ \\
\hline & Grand mean & 2.56 & $\mathrm{GE}$ \\
\hline
\end{tabular}

Table 3: Mean scores of respondents on the extent communities collaborates with government and non-governmental organizations for ffective development of literacy programmes for women.

\begin{tabular}{|c|c|c|c|}
\hline \multicolumn{4}{|c|}{$\mathrm{n}=68$} \\
\hline $\mathbf{S} / \mathbf{N}$ & Items & $\overline{\mathbf{X}}$ & $\begin{array}{l}\text { DECI } \\
\text { SION }\end{array}$ \\
\hline & $\begin{array}{l}\text { Communities through } \\
\text { community education } \\
\text { collaborates with government } \\
\text { and non-governmental } \\
\text { organization to; }\end{array}$ & & \\
\hline 15 & $\begin{array}{l}\text { Provides manpower training } \\
\text { for women literacy; }\end{array}$ & 2.29 & $\mathrm{LE}$ \\
\hline 16 & $\begin{array}{l}\text { Provide capacity building for } \\
\text { literacy development }\end{array}$ & 2.22 & LE \\
\hline 17 & $\begin{array}{l}\text { Develop curriculum for } \\
\text { women literacy programme }\end{array}$ & 2.42 & $\mathrm{LE}$ \\
\hline 18 & $\begin{array}{l}\text { Manage women literacy } \\
\text { programmes }\end{array}$ & 2.22 & LE \\
\hline 19 & $\begin{array}{l}\text { Formulate policy for women } \\
\text { literacy }\end{array}$ & 2.23 & LE \\
\hline 20 & $\begin{array}{l}\text { Provide resources for } \\
\text { women } \\
\text { programmes }\end{array}$ & 2.47 & LE \\
\hline 21 & $\begin{array}{l}\text { Evaluate women literacy } \\
\text { programme }\end{array}$ & 2.17 & LE \\
\hline & Grand mean & 2.28 & $\mathrm{LE}$ \\
\hline
\end{tabular}

Table 3 shows a mean score of 2.29, 2.22, 2.42, 2.22, 2.232 .47 and 2.17 for items 15, 16, 17, 18, 19, 20 and 21 respectively and a grand mean of 2.28. This indicates that the respondents agreed to a low extent that communities through community education 
collaborate with government and NGOs for effective development of women literacy in Enugu State.

\section{Discussion of findings}

The findings from the first research question revealed that communities' education to a great extent has enhanced the eradication of illiteracy among rural women in Enugu State. This is in agreement with the earlier study of [8] that community education offers women opportunity to gain literacy skills provides facilities that will facilitate literacy development of women. This finding may be as a result of awareness of the importance of literacy to the development of women in particular and the overall development of individual families and the community in general. However, home-visitation literacy programmes and targeting vulnerable and disadvantaged women were accepted to a low extent as ways of enhancing eradication of illiteracy through community education. This may be as a result of the nature of community education which is education targeted at the entire community for their collective needs. The individual needs of the members of the community are not given attention in community education. The result from the second research question revealed that community education has to a great extent contributed to the development of women literacy programmes in the state. In line with the above finding [2] noted that community education provides women literacy programmes, such as financial literacy, health and nutrition education, income generating skills and other activities. to promote learning and social development in the community. This finding may be as a result of the desire of every community to develop their women to participate in the overall social and economic development, in line with the general slogan that "if you educate a woman, you have educated a nation".

On the other hand, development of political literacy programmes, decision-making literacy skills and family planning literacy programmes were accepted to a low extent by the respondents. This may be as result of the patriarchal nature of the rural communities. Political structure, decision-making and reproduction (family size) are the prerogative of men and therefore women may not be exposed to literacy skills in those areas so as not to bring about conflicting roles in the communities.

The third research question revealed that communities through community education collaborated to a low extent with government and NGO's for effective women literacy development. This is in disagreement with the assertions of Nepal \& Grant that through community education communities collaborate with governments and NGO's to provide services such as capacity building and training of personnel, planning, executing, monitoring, and evaluation of women literacy programmes in the communities [11\&12]. This may be as a result of poor awareness on the part of the community leaders on the need for collaboration and accessibility of these bodies to the communities.

\section{Conclusion}

Literacy has become essential for collective advancement of all Citizens. For women it has a tremendous impact not only on their own development, but also on that of their family and communities. This study determined the extent to which community education has contributed to women's literacy development in Enugu State. Based on the findings made, the following conclusions were drawn. Community education has to a great extent contributed to women's literacy development in Enugu State. However, collaboration between communities, government and NGO's for effective women's literacy development is very low. Therefore there exists a link between community education and women's literacy development in Enugu State.

\section{Recommendations}

- Communities in the state should be sensitized on the need for collaboration with government, NGO's and religious organization for effective women's literacy development.

- Workshops, and seminars should be organized for community leaders de-emphasizing negative traditional practices against women.

- Individualistic approach to women's literacy should be encouraged in communities to target vulnerable and disadvantaged women

- Government, NGO's and Religious organizations should take up the development of literacy for women.

- Government should encourage women to embrace literacy through community education to meet the target of Education for All (EFA), by providing resources for women's literacy development

\section{Reference}

[1] Mekong, T.T.(2012) Community and the grass roofs. A Cross-Cultural theory of urban movement, London: Edward Arnold.

[2] Adeoye, F.F. (2012). Community and Literacy in Washington D.C.: The handbook of rural women, Thousand Oaks, CA; Sage Published www.uis.unesco.org.accessed January 132015 . 
[3] Baha'vlla'h, G.K. (2013). Descriptive literacy, London: Greenwich Press.

[4] Andora, C.O (2002) Literacy rates among young women in Benue State, Nigeria, Markurdi: Social Press.

[5] Abramahd'u, Q.W. (2013). Key Issues in Literacy and Women development, London: Athlone.

[6] Ukwuaba, L.C. (2012). Impact of Renewing women's lifeskill. Education Programme on Empowerment of rural women, Doctoral dissertation Enugu State University of Science and technology, Enugu Nigeria.

[7] Karl, W.T. (2010) Nature of reading in Women London: More house.

[8] Okedara, T.O. (2004) Community Safety and development Ibadan: New Agenda.

[9] Ayola, S.T (2002). Literacy statistics among rural women in Nigeria, Ibadan: University Press.

[10] Ukachi, P.E. (2009). Teach rural women to read and write, Ile-Ife: University Press.

[11] Nepal, H.C. (2006)The Journey of life: A history of literacy in America, Cambridge; Cambridge University Press.

[12] Grant, B.W. (2010) Element of Literacy; Newyork: Basic Press.

[13] Belfast, Q.T. (2010). Community education and women literacy in Asia, Voodoo: Asia Press.

[14] Dublin, O.F. (2009). Community and literacy among rural women in India, London: Frank Class.

[15] Enugu State Ministry of Commerce and Industries (2014). Statistical Report, 2014. 